OOPEN ACCESS

International Journal of Applied Research in Social Sciences

P-ISSN: 2706-9176, E-ISSN: 2706-9184

Volume 3, Issue 1, P.No. 1-11, March, 2021

DOI: $10.51594 /$ ijarss.v3i1.208

Fair East Publishers

Journal Homepage: www.fepbl.com/index.php/ijarss

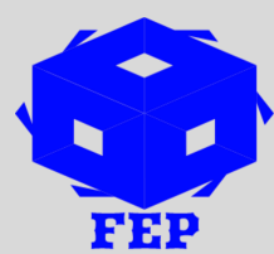

FEP

\title{
MUA'LLAGAT ZOHAYR IBN ABI SOLMA: ELEGANT PIECE OF ARABIC POETRY (1)
}

Yahya Saleh Hasan Dahami ${ }^{1} \&$ Abdullah Al Ghamdi ${ }^{2}$

${ }^{1}$ Associate Professor, English Department -Faculty of Science and Arts, Al Mandaq - Al Baha University, KSA

Previously: at Faculty of Languages and Human Sciences, Future University - Sana'a Yemen

${ }^{2}$ Assistant Professor, Department of Foreign Languages (English) - Faculty of Arts and Humanities Al Baha University, Al Baha, KSA

*Corresponding Author: Yahya Saleh Hasan Dahami

Corresponding Author Email: dahami02@gmail.com

Article Received: 23-02-21 Accepted: 13-03-21 Published: 30-03-21

Licensing Details: Author retains the right of this article. The article is distributed under the terms of the Creative Commons Attribution-Non Commercial 4.0 License (http://www.creativecommons.org/licences/by-nc/4.0/) which permits non-commercial use, reproduction and distribution of the work without further permission provided the original work is attributed as specified on the Journal open access page.

\begin{abstract}
Zohayr ibn Abi Solma is identified as an eminent poet who produced poetry distinguished with preeminence in courtly and virtuous love. The study employs an analytical and critical methodology, attempting to elucidate the influence of virtuous love narrated by the poet in the first verse lines of his great Mua'llagah. It commences with a terse introductory synopsis shedding light on the importance of classical Arabic and its involvement with poetry.

The paper attempts to prove, via the poetry of Zohayr ibn Abi Solma, the greatness of the Arabic classical poetry and demonstrate the aptitudes of the poet through his Mua'llagah. It is divided into four main parts. The first part deals with the greatness of the Arabic language then it moves to the second section that focuses on Arabic Poetry: Treasure of Wisdom. The third one sheds light on the poet's 'The Man and the Poet', and the last main part goes with an analytical and critical endeavor of the first ten verse lines of Al-Mua'llagah of Zohayr. It comes to an end with a conclusion.
\end{abstract}

Keywords: Arabic Literature, Arabic Poetry, Courtly Love Poetry, Courteous Arabic Poetry, Umm Awfa, Virtuous Poetry. 


\section{The Classical Arabic Language}

\section{INTRODUCTION}

The classical Arabic tongue is one of the foremost languages in the globe with its gorgeous literary conventions, practices, and customs. The position of the classical Arabic reflects the amount of Arabic talkers. It echoes the place that it has dominated and captured the history of the Arabic world as well as the substantial role it has enacted in ancient times and today in the evolution of the Arabic and Islamic world. Arabic is the language in which the elaborate, creative, and varied cultures are protected. Arbuthnot (1890), declares that in Arabia, the classical Arabic tongue has retained its uniqueness without very much dialectical modification (p. 23). It is abundant, profuse, and profound. The Arabic language is not only like a deep sea, but also it is like a bottomless ocean, the more you dive, you find it stimulating to reach the bottom. Several critics designate the Arabic language as the sea. It is a breathing active language throughout the ages.

As stated by Elinson, (2009), the Arabic literary language has its origins in the qasīda or ode of the pre-Islamic period that reflected Arabian authenticity and aesthetic. This setting of poetry in the desert, along with its shared opening section calling to mind the beloved's memory over the lost campsite (Al-Nasīb) permitted the poet to associate highly eloquent representative passages with allegorical expressions of nostalgia, desire, and despair (pp. 45).

The notion is supported by Dyck (1894), who pronounces that the Arabic classical language is one of the best tongues of the world because of two values; first concerning the richness of its literature and second due to the richness of its terminology (p. 40). "The Arabic language has not simply remained complementary to Islam but has been vital a medium of cultural and national restoration in the Arabic-speaking lands" (Dahami, 2019a). It is the national language of the Arabian nation starting from the Arabian Peninsula, North Africa, and the Fertile Crescent.

The Arabic language has arisen the best of it by the Holy Qur'an in addition to the ancient literary works - prose and verse - that have been conveyed to us. Critics comment that the "sciences were transmitted into the Arabic language from different parts of the world; by it, they were embellished and penetrated the hearts of men, while the beauties of that language flowed in their veins and arteries" (Lewis, 2002, p. 142). The idea is maintained by Gruendler (2002), saying that the "classical Arabic poetry is the literary canon from which medieval Arab linguists, genealogists, and other scholars take evidentiary verses (shawiihid) to support their arguments. In this way, ancient poetry 'judges' many a scholarly case" (p. 257).

Along with that, Faheem (1986), mentions that the Arabic language is the language of human science (p. 200). The classical Arabic language presents the excellence and superiority of phraseology. It is full of flashes of wit, tradition, and pageantry. History of the language literature as expressed by Al-Hashimi (1969), is that discipline that investigates the language and its conditions through its different ages. It is the discipline that searches its high position. In addition to what occurred for its inventors who left us with touched guidance (p. 3). Additionally, Mou'nis (1978), remarks that the unadulterated representation of the original Semitic that was developed in the Arabian Peninsula is the classical Arabic language that certainly initiated as a perfect culture. The Arabic language is not a sheer instrument of culture but a device and culture together (p.343). 
Moreover, the Arabic tongue has welded all other Arabic vernaculars and terminologies, shaping one of the finest in those dialects. It has gotten rid of the imperfections, which characterized other vernaculars. It is a concern of a nation that does not affect only a person or a group of people but the whole. The Arabic language is the tongue of the literary humanities, and the communication implement of poetry, rhetoric, and oratory. "The classical Arabic language is presented as the fulfillment and preeminence of phraseology and distinctive with flashes of keenness and spectacle" (Dahami, 2018a). It is the vein for poetry. "Arabic poetry raised a distinctive voice that reverberated across desert, village, and town. Among its functions at religious feasts and commercial fairs was its influence in confirming a common macro culture across the varying micro-cultures of Arabia" (Dahami, 2020; Allen, 2006: 78).

\section{Arabic Poetry: Treasure of Wisdom and Platonic Love}

Arabic poetry is an authorized measure to document Arabs' brilliant, fabulous, and marvelous deeds. It is immeasurable "in number and is transmitted from mouth to mouth. It was of great attraction where all listeners admired them, whatever people were, high or low, rich or poor. Poetry in the Arabic language is full of music and exquisite accent" (Dahami, 2015). The clannish genealogies with the gratitude of morals appreciate values like hospitality, bounty, audacity, valor, and tolerance. Typically, Arabic poetry, in addition to the universal poetry, has enduringly denoted the dominant literary maxim for the Arabic realm. Classical Arabic poetry is

rooted in the life of the people, that insensibly moulded their minds and fixed their character and made them morally and spiritually a nation long before Muhammad welded the variously conflicting groups into a single organism, animated, for some time at least, by a common purpose (Nicholson, 2013, p. 72).

Critics comment that they "do not reach the pre-Islamic age that we talk about until we find the classical Arabic has been perfected and reached the summit of its development" (Dahami, 2018b; Thaif, 1960, p. 121). Along with that, "Arabic poetry has always been regarded as the diwan al-Arab (the repository of Arabs), a resort in times of sorrow and happiness, of defeat and victory, an expression of the Arab people's cultural ideals and great aspirations" (Allen, 2000, pp. 65-66).

Tribes and clans of Arabs in Arabia used to maintain a means of supremacy, reinforced in the noteworthy land of Arabia primarily in the region of Mecca and Medina to which our poet, Zohayr ibn (son of) Abi Solma belongs. Mecca was a considerable focus in Arabia, and the life of the tribes were and still the most distinctive attribute of the period prior to the advancement of Islam. It was from Arabia that the elegant Arabic poetry has sprung because the dwellings were too much occupied with profitable, commercial, and dealings matters and varieties of stuff to give literature an occasion of evolution.

The poet is the ambassador and messenger of his clan. He is their guide in peace and their protector in war. Traditionally, the whole clan is pleased to divulge the advent of a poet, and singer of its dignity and glory. Since the Pre-Islamic age, the tradition of gathering and congregation in the evenings in tents around the versifiers and poets paying great thoughtfulness and care to people's lives rehearsed in elegant poetry invite listeners to reiterate and echo the common and unrestrained attribute that Arabic poetry has been captivated and enchanted its listeners ever since its creation. Critics confirm an influence about the Arabic poet stating that the conception of poetry as a variety of art is recognized afterward. "Generosity and hospitality have always featured prominently in Arab nomadic values, constituting an important aspect of murü’a [موروة muruwwa] (manliness)" (Brown, 2003). Furthermore, "The integration of the persona as a mature male into his society, one purpose of the horse description in the $f a k h r$ is to establish his courage, honor, loyalty, and generosity before other members of his community" (Dahami, 2018c; Motoyoshi, 2004, p. 60). 
Poets, philosophers, intellectuals, historians, storytellers are some of those who inspire Arab customs and contribute to the prevailing practice of the Arabic poetic tongue. They made the Arabic literary language one of the most prolific and creative in literature all over the place. They enjoy the blood of Arabia. Consequently, "The Arabic poetry, particularly the poetry of pre-Islam age, with its valuable tradition, is one of the major influences of the Arabic world" (Dahami, 2019b).

The "idea of poetry as an art was developed afterwards; the pagan sha'ir [poet] is the oracle of his tribe, their guide in peace and their champion in war" (Nicholson, 2013, p. 73). Critics delineate that poetry is the fashionable vehicle of literary communication, particularly in the pre-Islamic period. Every tribe had its poets, who freely expressed what they stroked and thought. Their unrecorded expressions flew through the lands quicker than arrows. The poets come home to the hearts and souls of all who listen to them.

\section{Zohayr ibn Abi Solma: The Man and the Poet}

Zohayr (also written as Zouhair, Zuhyair, or Zuhayir) ibn Abi Solma is one of the most prominent poets of the Pre-Islam era. Several critics have estimated Zohayr as one of the best three prominent poets besides Imru' Al-Gais ibn Hujr ibn Al-Harith and Al-Nabighah AthThubiani. Zohayr was born in 520 AD in Najd, and lived with his maternal uncles in Ghatafan, and was a wise poet who did not worship idols. His family was a poetic family in which his father was a poet and his sister Khansa was a famous poet too. Not only that but also his son Ka'b ibn Zohayr was a famous poet who composed one of the most famous poems in Islam about Prophet Mohammad (البرده) (البرد) called Al-Burdah).

Zohayr is a poet of a family who glorifies poetry. His father was a pronounced poet and Bashamah ibn Ghadiyr, his uncle to his mother, was also a distinguished poet. Zohayr is an outstanding poet of the pre-Islamic epoch who lived for almost ninety-seven years, from about "530 to 627 AD" (Az-Zawzani, 2011, p. 71). He is portrayed as an honorable and bighearted individual who wrote his poems in admiration of men who seek peace and settlement. The name of the father of Zohayr, according to Al-Asfahani in his great book of Al-Aghani - The Songs - (2008), is Rabia'h ibn Riyah ibn Gurrat ibn Al Harith ibn Mazen ... ibn Nezar (p. 226).

Abo Solma ibn Rabiya'h is an offspring of the tribe of Mozayna.

Having had some dissatisfaction with the folks of his tribe, Mozayna, Abo Solma left them and came with his family to live with his maternal uncles of Murrah. He, at that juncture, settled with Bano Abdallah ibn Ghatafan, neighbors and lineages of Murrah, in an area called Al-Hajiz of Najd near Al Madinah where his descendants continued to exist after Islam (Dahami, 2019c).

Commonly, the poem of Zohayr can be appraised as one of the thoughtful pieces of literature of Arabic concord, for it encompasses Arabic heritage. Unlike the famous poets of AlMualagat, Zohayr had a different distinguished style in writing his poems. They are called $\mathrm{Al}$ Hawliat (الحوليات) which indicate or refer to annuals. Abo Zaid (1993), mentions that Zohayr used to write each of his poems in four months and to refine it in another four months then deliver it in the next four months, that is a year (p. 14).

\section{A Poetic and Literary Analysis of Some Selected Verse Lines of Al-Mu'alagah}


Normally, Arabic poetry, as the same as the poetry of other languages and nations, has always specified the focal literary expression and communication for the Arabic nation. With its perpetual depending on sound, undertone, and connotation, Arabic poetry plays a crucial part with its cadence, rhyme, rhythm, metaphor, and attractive tones. As the great contemporary Arab poets have frequently advocated, poetry may have a principal approach to the transformations ascending in cultures and civilizations. Al-Mua'llagah of Zohayr is certainly one of the excellent pieces of ancient Arabic poetry that was created before the shining of Islam. It has a magnificent and praiseful status of Arabic literary history that remains even today. Al-Mua'llagah is a long piece of poetry that is used to be precisely hung on the sides of the Holy Ka'abah of Holy Mecca.

The hanging pieces of poetry on Al-Ka'abah are done in that way because they are judged and considered as the most important, the most noteworthy and the marvelous poems ever composed and narrated during the epoch of pre-Islam. The processes of judging, evaluating and assessing the various poems presented have been taken in annual literary councils in Souq Okath near the town of At-taif (الطائف). The councils were organized by the attendance of great poets who were esteemed as judges and referees. The selected poems to be called Mua'llagat, according to critics and literary historians, are only ten, and other literary historians mention that they are only seven poems. Al-Mua'llagah of Zohayr is estimated to be third in rank among the seven/ten Mua'llagat. The poet commenced his Mua'llagah with a memorandum with his wife Umm Awfa who requested divorce because of his second marriage. Zohayr initiated the poem with several lines describing his admiration and virtuous love for Umm Awfa. Al-Mua'llagah of Zohayr starts with the following lines.

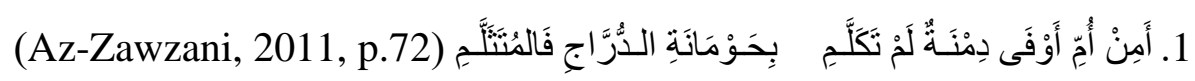

1. These ash-covered ruins, that did not talk to me, in Hawmanat Al-Darraj and Al-

Mutathallami, where they ever the dwelling place of Umm Awfa (Maso'd, 2013)

Zohayr ibn Abi Solma commences this poem like all of the pre-Islamic poets, who, in the opening of their poems, used to stand on the remnants of a beloved. The poet asks about the homes and lands of Umm Awfa in which he points out the years that have passed. These years passed to the degree that Umm Awfa no longer identifies him and their virtual and platonic relationships. The lands that were inhabited by Umm Awfa are names of belonging the poet wanted to make a piece of touchable evidence about his kinsmanship, so he mentioned places such as Hawmanah (حومانه), Ad-Daraj (الدراج), and Al-Mutathalim (المتنلم); all of them are names of the places that Umm Awfa dwelled in.

By going back to the dictionaries, we find in the first verse line, Arabic names of objects were renowned and of helpful use to people of the time, such as the word dimnah/dimnat (دمنة) which refers to what is blackened from the traces of a house with dust and ashes. The word dimnah has more other meanings such as hatred and the saddle but the suitable is the first one that refers to blackness. This first line indicates that the poet inquires about something he knows the answer but he wants to make certain. He, implicitly, states that his question is presented with a sort of doubt to verify that the long period of being absent, he is not sure of the places he used to be familiar with long years ago. Another picture can be envisaged that the poet wishes to speak with the people of that place but unfortunately, no one can talk with him because they all departed the area and what remains is only the soulless residues of some 
houses. It is a profound feeling of the poet to remember his beloved - previously divorced wife Umm Awfa.

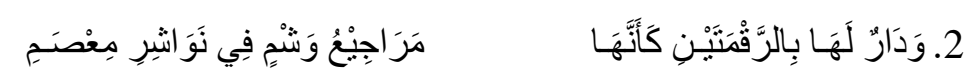

2. The traces of her abode in Ar-Raqmatain resemble fresh tattoo marks on wrist veins The poet Zohayr bin Abi Salma started this poetic line telling about the homes to emphasize the importance of the place for him and to make the reader attracted to the following in reference to the importance of both, the place and its inhabitants. It is not hidden to critics that the poet mentioned the residence as a predicate after he calculated the number of houses that he and his beloved existed. They are the same homes, which urged his sentiment as it is seen in the previous poetic line, which symbolizes places of memory in the imagination of the poet. The poet associated between the two verses to make the same association between both, the homes and those who inhabited the homes. Umm Awfa is his previous beloved wife who made his heart and mind occupied with her. We are also aware of the ingenuity of the poet who wanted to make the ownership of such a place of his beloved. He dedicated to the word alraqmatayn, which are two residences, the first is near Al-Madinah - previously known as Yathrib - and the second is located near Basra of Iraq.

The poet carries on to explain the importance of the residence and its people, where the residues of the places affect his soul and spirit. These dwellings are still pinched in his heart and memory so that he cannot stop thinking about them because they remind him of Umm Awfa. The remaining relics, according to the poet's description, are edifices throughout the ages; continue to evoke his emotions and memories. The reader and critic can understand the gorgeous profound connotations that the poet used to enlighten his nostalgia of the feelings inside him towards Umm Awfa. It may be said that the poet presented his speech with a manner of doubt about these residences, do they belong to Umm Awfa or not. Then, he likened the relics with a fixed tattoo on the wrist as a sign of proof of friendliness after passing for a long time. This sort of affection is firm as the existence of these dwellings has withstood the winds and rain of the ages that have passed for more than twenty years.

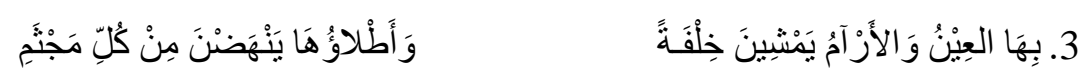

3. Lo! Wide-eyed cows and white, swift antelopes, successively roam; their calves and fawns awaken and get up from their resting places

In his conception of the environment in which the poet and his people live in his time. $\mathrm{He}$ infers his drawing of what he has in mind with real-life images and analogies, such as his saying at the beginning of this poetic line (بها العين) biha aleayn which means that these lands or places carry both sorts of cattle such as cows. The third word (الارام) al-aram, denotes the antelope which is characterized by pure whiteness. The poet refers to both the cows and antelopes, which inhabit that place because they are of great importance and benefit to people. They also refer to the process of continuous movement. The cattle form groups in which a group leaves the place another group arrives. It is understood that the significance of such group is clear when the poet mentions the words (يَمْنَيْنَ خِلْفَةًا) yamshin khilfatan denoting to a continuous process of living. It is a portrait of tribal life, which does not stay still, but a continuous circle of life. The word (يَمَنِينَن) yamshin means to walk and the word (خِلْفَةًَ) khilfatan means one replaced by another. The conceived picture is the permanence and persistence of walking. The poet, in a poetic glimpse, left us except the process of active life 
within the two types of cattle not forgetting the constant movement of the cattle accompanied by their children.

The poet, in this poetic line, talks about the rank and status of his beloved, after mentioning the relics and homes that have agitated his conscience and feelings in the two previous poetic lines of this poem. In this line, the curve of the news moves in a circle of places that aroused the poet's excitement where life before the war was blessed with splendor and beauty in constant renewal. This is indicative of the phrase as mentioned earlier, yamshin khilfatan that indicates and designates the continuation of that renewed and continuous exquisiteness. The contemplative reader for this verse line realizes that if a crowd left the place, another crowd came. We can also comprehend that if one thing goes, it is replaced by something else to make the place active with life. The poet's great potentiality in making metaphorical comparisons and imaginative portrays is clear. He symbolizes a kind of renewed and continuous exquisiteness through the walk of the antelopes.

The poet portrays the cows and the antelopes, as groups, in a constant movement; one against another, walking in hordes and groups. The first (group) is coming and the other is leaving. The profound meaning here can be understood so symbolically that we imagine if a herd goes on, another herd comes. In the same context, we can sense the saying of Allah, "who made night and day behind him", that is, to succeed each other to indicate the continuity and renewal of life.

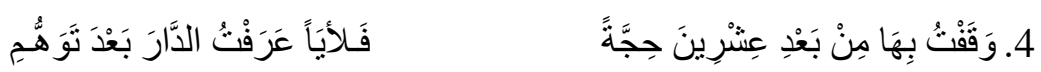

4. There I stood after being away for twenty long years, and recognized the abode with difficulty, after some exertion and uncertainty

In the previous three lines, the poet mentioned a description of a deeply intimate memory in order to solace himself from the spiritual burdens after the passage of lean years on those dwellings, in a period of time exceeding twenty years; he mentions the homes and lands of loved ones. As it is the habit of this great poet - the poet of wisdom and peace - he expresses and speaks of a psychological feeling that he suffers, and metaphorically speaks about the exhalations of nostalgia that indicate how much he loves those who lived and settled in the mentioned lands. Such exciting feelings are understood

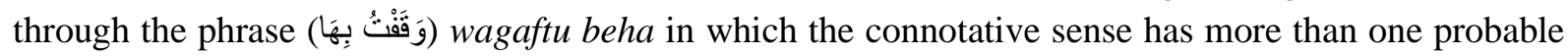
interpretation. It might be a physical standing by the body and all other senses sharing the feelings; it might be symbolically abstract standing by thought because poetry is abstract in most of its images and representations. It is most likely that the standing is both physical and mental; physical because the poet has reached the place, he knew, after conjecture and speculation. We come to realize that through contemplating the phrase (بَحْدَ تَوَهُِْ ba'da tawahumi, which refer to the state of the poet in realizing the place 'after a delusion'. The poet here remembers the form and position of the place, through which he recalls the memories of the original and beautiful time in which he created the paths of places where the movement and travel return between them.

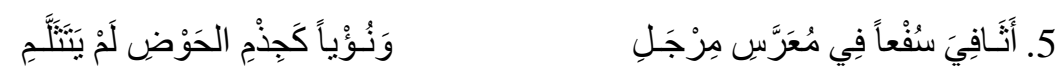

5. I discerned the darkened stones that once supported the metal pot, and noticed that the little stream, dug up around the tent, still holding together, with no cracks

After recognizing the places of Umm Awfa with difficulties as a result of the long period since they separated which is mentioned in the previous verse lines particularly the fourth line, the poet in this fifth verse line continues describing the home of his wife and the surroundings 
of this home. He explains his realization of the area particularly the black stones that are made for cooking using vessels or metal bowls. In addition to that, there is a small waterway surrounding the house of Umm Awfa as if it is a pool. Such traces are signs for him to confirm his knowledge of the place.

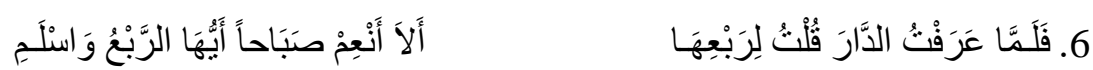

6. As I recognized the abode, I said to the abandoned place: May your morning be blessed $\mathrm{O}$ dear place, and may you be protected from harm

The poet starts this verse line with a famous phrase, 'ala 'aneama sabahaan', a method of greeting among Arabs in the period prior to Islam which means 'Have a blessed and good morning'. Arab used to say 'I wish you a good morning' or 'Have a good morning'. When the poet realized the residences, he saluted them wishing them, referring to the places, peace, and long-living. The poet says that 'when I reached her dwellings, I addressed the people of them with salutation saying have a nice day. I wish you peace and prosperous life.

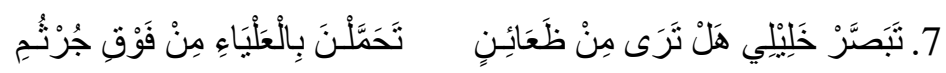

7. Look closely my friend, do you see women carried on howdahs atop camels, crossing elevated tracts, above the Jurthum brook

This verse line shows that the poet is obsessed with crying rather than looking at the places he mentioned. He asked a question but no one beside him to answer. The question is forwarded to any reader or listener of this poem to share his views and feelings. The poet asks if the addressee can see women (ظَعَائنِ) carried by the ships of the desert traveling through highlands - metaphorically referring to a specific land. The connotative sense here is that the poet is taken by affection to a great extent in which he feels it is impossible to find what he seeks.

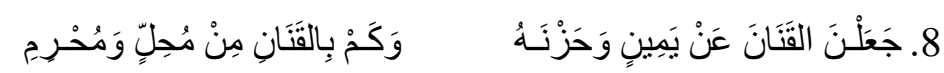

8. They traveled, Qanan Mountain and rugged land to their right; many are the Qanan days, where rituals are at times observed and, at other times, people are of them absolved

The idea of this line is that the poet is in a difficult situation to the degree that his love for his woman led him to travel to a very far land full of complications in order to see her. $\mathrm{He}$ declares that his travel may take him to the land of enemies, wishing not to be discovered otherwise he will be captured or even eradicated.

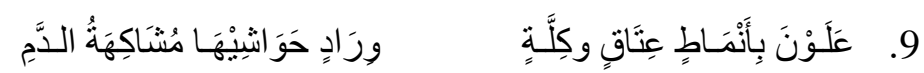

9. They threw costly ornate covers on the howdahs, with decorative borders, deep vivid red in color, like blood.

In this line, the poet extends the idea presented in the previous line. Still, the point is revolving around the women traveling on the howdahs but the focus is on the setting of the howdahs. Zohayr imaginatively delineates the decorative howdah with the best of cloth and decoration in which he wishes to be for the traveling women expecting Umm Awfa to be among them. The word, (الكَلَّدة) Al-Killah is a type of delicate clothing, which is a thin garment that is placed over a thick one. Its edges are roses, reddish as if it is the color of red gum. 
Alternatively, it is similar to the blood in its redness. Here, the scene of (الظعينة) Al-Da'aynah or the woman describes the woman and her howdah and what her scene looked like. The luggage has been carried and arranged so that the howdah was covered with bedspreads and underneath Al-Killah. The howdah now became decorated with a red color.

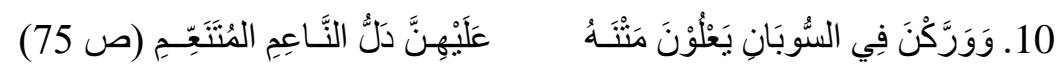

10. They mounted the posterior portions of their camel backs, as they sallied forth over the Soban land; their features disclosing luxurious living, contentment, and pleasurable ease

The general meaning of this line indicates that the poet Zohayr mentions that the women mentioned in the previous line are known to be traveling on decorated howdahs with the comforts of luxurious curtains and soft clothes, passed through the highlands called As-Suban (السُوبَانِ). One of the traits of the women mentioned is that they are known with morals, ethics, and dictums. They are defined as good human beings.

\section{CONCLUSION}

Zohayr ibn Abi Solma is no doubt a platonic lover; he did not forget his wife for more than twenty years after she demanded a divorce. He has proven the elegant virtual love poetry with masterfulness in figuratively portraying his wife Umm Awfa through the places she dwelled in. It is the word that Zohayr has perfected in his Mua'llahah. He started it, in the first verse lines, with courtly love poetry describing his loyalty to his wife before diving into the sea of wisdom and peacemaking. The first ten verse lines have proved the great capability of the poet to deal with virtuous love issues connected with the moral ethics of life of Arabs before the coming of Islam.

Al-Mua'llagah of Zohayr deserves to put him third among the limited poets of Mua'llagat. This eminent hanging poem of Zohayr, equally all his poetry, is essentially extraordinary for several motives among which his verse bears extraordinary issues such as courtly love poetry. His lines are written with, perception, appeal, and good sense using graceful language. The paper has foreseen inspecting the figurative, metaphorical and aesthetic pictures in AlMua'llagah of Zohayr ibn Abi Solma. As the examination shows, it pursued the logical scheme placed on the most considerable sources. Al-Mua'llagah depicts unique Arab values and ethics in the pre-Islamic age.

\section{References}

Abo Zaid, A.I. (1993). Zohayr Bin Abi Salma: Poet of Wisdom: A Literary Study of his Poetry and Explanation of his Poetry. Beirut: Ezzuddin Corporation for Printing and Publishing.

Al-Asfahani, A. (2008). Kitab Al-Aghani (The Book of Songs), Vol. (10) (3 ${ }^{\text {rd }}$ Ed.)., Beirut: Dar Sader Publishers.

Al-Hashimi. A. (1969). Jawahir Al-Adab fi Adbiat wa Insha Lughat Al-Arab (Jewelry of Literature in Literatures and Growth of the Language of Arabs) Vol. 2. (27 ${ }^{\text {th }}$ Edn.), Egypt: Al-Maktabah At-Tejariah Al-Kubra.

Allen, R. (2000). An Introduction to Arabic Literature. Cambridge: Cambridge University Press.

Allen, M. (2006). Arab. London and New York: Continuum. 
Arbuthnot, F. F. (1890). Arabic Authors: A Manual of Arabian History and Literature. London: William Heinemann.

Az-Zawzani, A.A.A.I.A. (2011). Al-Mua'llaqat As-Saba', (the Seven Hanging Poems of Arabs). Beirut: Dar El-Ma'refah.

Brown, J. A. C. (2003). The Social Context of Pre-Islamic Poetry: Poetic Imagery and Social Reality in the Mu'allaqat. Arab Studies Quarterly, 25(3), 29-50.

Dahami, Y. S. H. (2020). The Eminence of Poetic Arabic Language: Lamiyyat Al Arab of AshShanfara Example. International Journal of Applied Research in Social Sciences, 2(1), 8-19.

Dahami, Y. S. H. (2019a). Influence of the Arabic Language: The Muwashshah of ibn Sahl Al-Andalusi an Example. American Journal of Humanities and Social Sciences Research (AJHSSR), 3(1), 58-65.

Dahami, Y. S. H. (2019b). Thu Al-Ausb'a Al-'Adwani: An Arabic Poet of Acuity with Eternal Arguments. International Journal of Linguistics, Literature and Culture - LLC, 6(1), 37-50.

Dahami, Y. S. H. (2019c). Zohayr ibn Abi Solma: The Man of Wisdom and Peacemaking. International Journal of Recent Innovations in Academic Research, 1(1), 71-84.

Dahami, Y. S. H. (2018b). Tarafah ibn Al-A'bd and his Outstanding Arabic Mua'llagah. International Journal of English Literature and Social Sciences (IJELS), 3(6), 939947.

Dahami, Y. S. H. (2018a). The Arabic Tongue: A Worthy Language. European Journal of Language and Literature Studies, 4(4), 81-90.

Dahami, Y. S. H. (2018c). The Magnificence of Arabic: Orwa ibn Al-Ward an Epitome. International Journal of English and Literature, 9(7), 79-87. DOI: 10.5897/IJEL2018.1216.

Dahami, Y. S. H. (2015). The Contribution of Arab Muslims to the Provencal Lyrical Poetry: The Troubadours in the Twelfth Century. Journal of Arts, 27(1), King Saud Univ., Riyadh. pp. 1-19.

Dyck, E. A. (1894). History of the Arabs and their Literature: Before and After the Rise of Islam. Ig. V. Kleinmayr \& Fed. Bamberg in Laibach.

Elinson, A. E. (2009). Looking Back at Al-Andalus: The Poetics of Loss and Nostalgia in Medieval Arabic and Hebrew Literature. Boston: BRILL.

Faheem, H. (1986). The Story of Anthropology: Chapters in the History of Human Science. Kuwait: The National Council for Culture, Arts and Literature.

Gruendler, B. (2002). Medieval Arabic Praise Poetry: Ibn Al-Rumi and the Patron's Redemption. Routledge.

Lewis, B. (2002). The Arabs in History. Oxford: Oxford University Press.

Maso'd, Mahmoud Abas (2013). The Mu'allaqa of Zohayr Bin Abi Solma: Translated by: Mahmoud Abbas Masoud, DAR Alnour Translations. Retrieved on 1/12/2020 from https://www.facebook.com/123398957856841/posts/153680438162026/

Motoyoshi, S. A. (2004). Description in Classical Arabic Poetry: Wasf, Ekphrasis, and Interarts Theory. BRILL.

Mou'nis, H. (1978). The Civilization: A Study in the Basis and Factors of its Origination and Development. Kuwait: The National Council for Culture, Arts and Literature.

Nicholson, R. A. (2013). Literary History of the Arabs. NY: Routledge. 
Thaif, S. (1960). History of Arabic Literature: Ignorance Age. Cairo: Dar Al-Ma'arif of Egypt. 